\title{
ISO 9002：神崎工場における認証取得の実体験
}

\author{
新王子製紙株式会社神崎工場 三 宅亮

\section{The way to obtaining ISO 9002 Resistration by Kanzaki Mill} \\ Makoto Miyake \\ New Oji Paper CO., LTD., Kanzaki Mill
}

We started the preparation for obtaining ISO 9002 Resistration by Kanzaki Mill in December 1992 and succeded it in June 1994.

Following are our experiences to be successful in obtaining ISO 9002 Resistration.

\section{1.はじめに}

現在，ISO 9000 シリーズ品質保証の国際規格に基 づく品質システム認証が, 企業にとっての関心事の一 つとなっている。

ISO 9000 シリーズ規格は，1987 年に国際標準化機 構（ISO)によって制定され，1991 年には JIS Z 9900 シリーズとしても発行されている。

わが国でも，1993 年 11 月に財日本品質システム審 査登録認定協会 (JBA) が設立され, ISO 9000 シリ 一ズに基づく審査登録制度が運用されるようになった。 以後, 認証を取得する企業（事業所）も増えてきてお り, 認証取得している企業は千社前後に上っていると 思われる。

わが国の製紙産業でも今後の国際化や, 既に認証を 取得しているユーザーからの要望で, ISO 認証取得の ニーズが高まってくると思われる。

神崎工場では 1992 年 12 月より認証取得の作業を始 めたが, 初めての経験ゆえに, 規格の解釈, 規格要求 項目に対してどのレベルまで実施する必要があるのか 等の試行錯誤を繰り返しながら,やっと 1994 年 6 月 に認証取得にこぎつけた。

ISO 9000 シリーズ規格の内容や審査登録制度につ いては多数の成書や総説が出ているので, 本稿では 我々の認証準備から取得までの実体験をまとめた。

\section{ISO 9000 シリーズ規格認証取得の動機}

1992 年になってから, 貿易部より ISO 認証取得に ついての問い合わせが増加し, 文献, 新聞等で ISO 関連の記事が多くみられるようになった。そこで, 研
究開発本部（旧神崎製紙）を中心に調査を行っていた が

（1) 神崎工場は生産量の約 $20 \%$ を輸出しているが, 海外，特に EC 諸国へはISOの認証を受けない と輸出できなくなることが心配された。

(2) ファックスやプリンターのメーカーである電気 メーカーの多くは既に認証を取得しており，他社 に先駆けて認証を取得する事で感熱紙や静電記録 紙の販売で有利に立てる。

(3) 工場全体で認証取得作業を行う事で, 品質管理, 品質保証に対する意識が高まる。

(4) 工場の品質管理体制の整備改善が出来る。 等の判断から認証取得に取り掛かった。

\section{3. 認証取得の準備}

3.1 取得する規格の選択

ISO 9000 シリーズ規格は, 購入者が要求する品質 の製品やサービスを安定的に継続して作り出すための 仕組み，つまり品質システムが備えるべき条件を定め た 9000９004の5つの国際規格のことをいう（表 1)。 このうち, 9001 から 9003 が品質保証に関する規格で, 認証を取得しょうとする企業は, 9000 に示された指 針に従って規格を選択する。

大ざっぱには, 9001 は会社全体の品質保証システム, 9002 は工場或いは製品単位の品質保証システム, 9003 は鉱山会社のように製造工程を持たない工場の 品質保証システムといえる。

神崎工場の場合, 品種は多いが, 規格, 仕様の決ま つたものを繰り返し生産している丁場であることから 9002 で認証を取得した。 
表 1 ISO 9000 シリーズ規格

\begin{tabular}{c|l}
\hline ISO 9000 & 品質保証規格の使い方 $\quad 9001$ 9003の選択の指針 \\
\hline ISO 9001 & 設計, 開発, 製造据え付け及び付帯サービスに於ける品質保証モデル \\
\hline ISO 9002 & 製造及び据え付けに於ける品質保証モデル \\
\hline ISO 9003 & 最終検査及び試験に於ける品質保証モデル \\
\hline ISO 9004 & 品質管理の指針 \\
\hline
\end{tabular}

研究開発本部と工場が協力して行う開発品のテスト は，顧客である研究開発本部が規格・仕様を指定して 注文してきたものを工場が製造するものであって， 9001 の要求項目である設計管理に該当せず，契約内 容の確認の項で処理できると判断した。

ちなみに, 1994 年 7 月までに(財)日本品質保証機構 （JQA）で約 550 社が認証を取得しているが，その中 の $1 / 3$ は $9001 ， 2 / 3$ は 9002 で取得している。

\section{2 認証を受ける製品の範囲}

販売戦略の面からだけ考えると，感熱紙の製造工程 だけの認証を取得すれば充分であると考えられたが, 神崎工場の場合, 設備も要員も感熱紙専用でないため, 感熱紙の生産と他品種の生産を区別して管理すること が難しい，工場全体で認証取得作業を行うことで品質 管理・品質保証に対する意識が高まる, 工場の品質管 理体制の整備改善が出来る，等から神崎工場で製造す る全品種（表 2）を対象とした。

3.3 規格の適用される組織範囲

神崎工場では，カッター，スリッター以後の工程は 別会社である KS ウイング神崎事業所に委託している ので，KS ウイング神崎事業所を含めて認証を取得し ないと意味がなかった。

KS ウイングを神崎丁場の品質システムに入れるこ

表 2 認証を受けた製品の範囲

\begin{tabular}{|c|c|}
\hline 分 類 & 品 \\
\hline 事務用 紙 & ノーカーボン紙 \\
\hline 塗 工 紙 & アート紙，コート紙，合成紙塗工紙 \\
\hline \multicolumn{2}{|l|}{ キャスト紙 } \\
\hline 板 & アートポスト \\
\hline 情報 用 紙 & $\begin{array}{l}\text { 感熱紙, 合成紙感熱紙, 静電記録紙, } \\
\text { 熱転写紙, インクジェット用紙 }\end{array}$ \\
\hline 加 工 品 & 粘着紙, 防錆紙 \\
\hline 特 殊 紙 & 昇華転写紙 \\
\hline
\end{tabular}

とが出来るかどうか心配であったが，神崎工場と KS ウイングの連絡空口を一本化すること, 神崎工場の品 質保証マニュアルに従って担当する工程のシステムを 構築し, 内部監査, 経営者による品質システムの見直 しも行うことでシステムに入れることが出来た。

総務，安全，環境部門は，品質に直接影響する部門 でないと言うことで適用組織から除いた。

\section{4 審査・認証機関}

認証を取得しようとする企業は，選択した品質シス テムの規格に従って品質システムを構築し, 審査・認 証機関に審査を申請する。申請を受けた審査・認証機 関は企業に出向いて

(1) 品質システムが構築され文書化されているか

(2) システムが実際に運用されているか

について審査を行う。この審査に合格すると ISO 規 格の認証企業として登録される（図 1)。

従って，認証を取得しようとする企業は，どの機関 で審査を受けるか決める必要がある。現在, 国内で審 査・認証を行っている機関は数多くある（表 3)。大 手の審査・認証機関は財)日本品質保証機構（JQA） (旧名(財)機械電子検査検定協会 (JMI)), Lloyd's Register QA (LRQA), Bureau Veritas QI (BVQI) の三機関であり，大多数の企業はこの三機関から認証 を受けている。

国際的に認められた認証機関であると言うことも重 要ではあるが, 親切に相談に乗ってもらえ，指導して もらえる認証機関を選ぶことがもつと重要である。

我々は, 審査実績, 海外認証機関と相互認証してい ること, 品質マニュアル作成等の指導が受けられるこ と等から JQA で審査を受けることとし， 93 年 1 月に 受番の申請を行った。

3.5 認証取得プロジェクトチーム

認証取得の作業は全て工場で行った。リーダーと専 任担当者 2 名 (事務局)，工場各部門メンバー 17 名の 計 20 名で, ISO 認証取得プロジェクトを編成して取 得作業を行った。

メンバーは, 各部署で仕事の内容が最もよく判った 


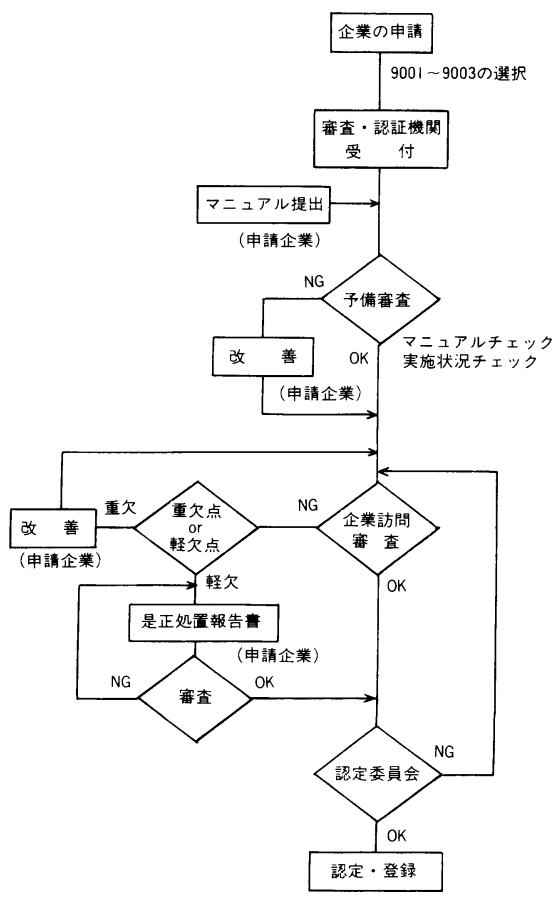

図 1 認証登録の仕組み

表 3 賽査・認定機関

\begin{tabular}{|c|c|}
\hline 日本品質保証機構 & (JQA) \\
\hline 日本規格協会 & (JSA) \\
\hline 日本電気用品試験所 & (JET) \\
\hline 日本電子部品信頼センター & $(\mathrm{RCJ})$ \\
\hline 日本海事協会 & $(\mathrm{NK})$ \\
\hline 日本ガス機器検査協会 & (JIA) \\
\hline 高圧ガス保安協会 & $(\mathrm{KHK})$ \\
\hline 日本検査キューエーKK & (JICQA) \\
\hline 纎維検査協議会 & (JTIC) \\
\hline 日本能率協会 & (JMA) \\
\hline 日本化学キューエー株式会社 & \\
\hline Lloyd's Register QA & (LRQA) \\
\hline Bureau Veritas QI & (BVQI) \\
\hline Det Norske Veritas QA & (DNVQA) \\
\hline Rheinland G. & $(\mathrm{TUV})$ \\
\hline
\end{tabular}

人であることが重要で，規格の適用される各部署の技 師（課長クラス）仪は係長の中から選任した。スター 卜当初, 各メンバーは認証取得作業を各自の仕事の合 間に行っていた。しかし，規格の内容が分ってくるに つれて, 文書の作成は勿論, 文書管理, 課員の教育, 実施状況のチェック等の作業量がどんどん増えてきた。
特に, 審査前の 3 力月は認証取得作業に掛かりきりと なっても間に合わず，回りの人の手助けが必要となっ た。

\section{6 認証取得計画}

認証取得の目標を 94 年 3 月に置いて 92 年 12 月に 認証取得作業を開始した（図2)。

途中，合併にともなう作業が入って遅れた部署が出 て来たことから 94 年 3 月の受番予定を 5 月に延期し た。文書化に非常に手間取り, 番査を受ける体制が不 十分であったが, 延期された 2 五の間に, 文書の整 合性チェックや内部品質監査による是正を行う時間が とれて，結果的には延期されたことがよかった。

3.7 文 書 化

文書化は後で述べる内部品質監査と共に ISO 9000 の大きな特徴の一つである。

認証取得活動で最も重要なものは品質マニュアルを はじめとする文書化である。神崎 I場では品質マニュ アルを頂点とした体系で文書の整備を行った（図 3)。

文書化する場合, 最初に品質保証マニュアルを作成 し, マニュアルに従って下位の文書を作成していく方 法と，下位の文書を作成・整理しそれらをまとめあげ て品質保証マニュアルを作成する方法がある。既に品 質管理・品質保証の体制が整備され, 文書化もできて いる場合には後者の方がよいであろうし，それらが不 十分な場合は前者の方がよいであろう。

神崎工場の場合, ISO 9002 規格の要求事項の大部 分は実施されていたが，文書化が不十分で統一された 基準で実施されていない面があった。そこで, 最初に 品質保証マニュアルでやるべきこと, そのやり方を統 一し，それから下位の文書を作成する少がよいと判断 した。

文書化で重要なことは，理想ではなく現状をありの ままに文書化することと品質保証マニュアルをはじめ 上位の文書では細かく規定しないと言うことである。

ISO 規格では，「…する。」とは書かれているが, 「…の方法で...する」とは書かれていない。やるべき ことは決斿れているがやり方は冬企業独自のやり方 でよい。

日本の企業であれば必ず品質システムは持っている はずで，ただきっちりした文書化がされていないだけ であるから，現実にやられていることを文書化するだ けで十分である。

(1) 品質保証マニュアル

品質保証マニュアルは事務局が,「標準化と品質管 理」(日本規格協会 92 年 1 月 6月）の三浦昭夫氏の 連載記事を参考に,JQAの指導を受けて作成した。 


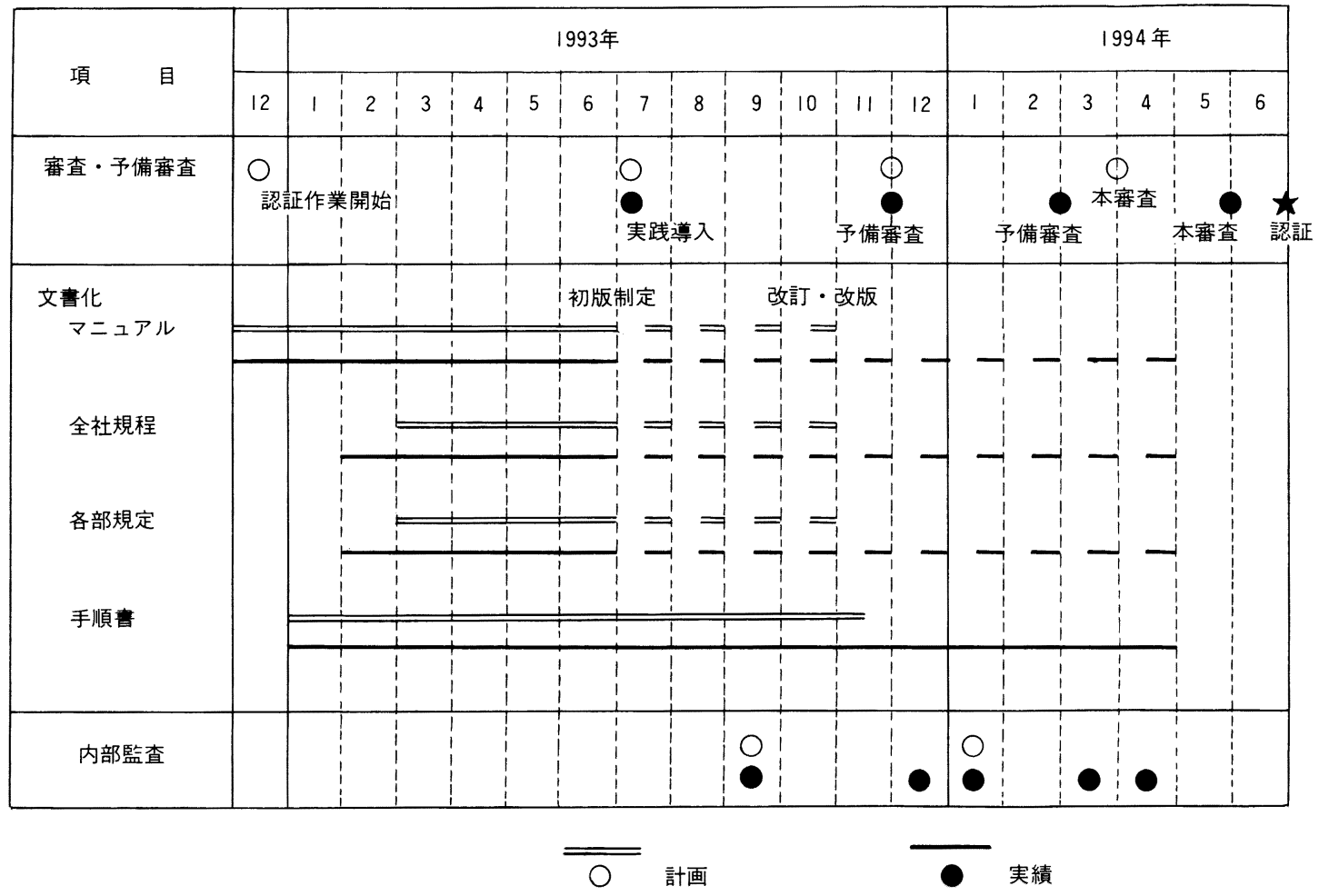

図 2 認証取得スケジュール

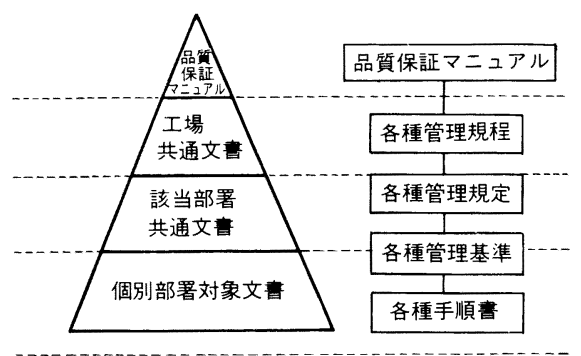

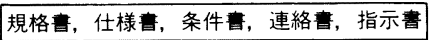

図 3 文書体系

品質マニュアルの第一版は予定通り 93 年 6 月にマニ ユアルの第 1 版が完成した。しかしながら，品質保証 マニュアルに基づいて実際に作業を行うと種々の改訂 が必要となり，現在使用中のマニュアルは第 7 版であ る。

（2）工場共通規程，各部署の規定

工場共通規程は事務局が原案を作成し，メンバーの 会合で修正を行い 93 年 6 月に第一版が完成した。各 部署の規定は，各部署のプロジェクトメンバーが工場 共通規程の作成と平行して作成した。
実際に運用を始めると，工場共通規程と各部署の規 定との整合性がうまくとれなくて，改訂・改版を操り 返した。実際，文書管理規程，不適合品管理規程等は 5 回以上改訂を行っている。

我々が文書化に非常に手間取った原因の一つは，工 場共通規程と各部署の規定を平行して作ったことによ るものであった。実際に作業を始めると, 出来るだけ 早く文書を作りたいという気持ちが先行して, 出来る ところから文書を作っていってしまった。今になって 考えると, 工場共通規程で主管部署, 連絡文書・記録, 手法などをきっちりと決め, それから共通規程の取り 決めに従って各部署で文書化する方が早道であったで あろうと反省している。

\section{(3) 手順}

手順は実際に作業を行っている係長, 職長が作成し た。手順は ISOの内容（品質保証マニュアル）にと らわれずに文書化した。日常業務を文書化するだけで あるから簡単に出来ると考えたが，日常業務の合間の 作業で時間がうまくとれないことと，文書を書き慣れ ていないことが重なって非常に時間が掛かった。

実際に作業をしている人が実際に行っているとおり に書いたものであるので改訂はほとんど行っていない。 
上位文書と手順に不整合があった場合は上位文書を改 訂した。

各作業についてどの範囲までを文書化すればよいの かがよく分らなかったが, 実際に監査を受けてみて, 品質に直接影響するような作業についての手順書は必 要であるが, しかし, 機械の操作, 巻取りの枠替え, 備品の取り替え等品質にそれほど大きな影響を与えな い作業については，作業マニュアルが完備されて OJTなどで全員に周知徹底されていれば，あらため て手順書を作成する必要はない様に思われた。

\section{8 文書配布}

ISO 規定では，文書を必要部署に配布するよう規定 されており, 各部署が作成した規定, 基準, 手順を少 しでも関係がありそうな部署には配布するようにした。 その結果, 管理する文書が多くなり, 文書管理に手間 が掛かり，そのうえミスも多く出た。

本審査でも，配布された文書のどの部分が関係する のか, また本当にこの文書に従って作業を行っている のか等の疑問が投げかけられた。そこで複数の部門間 に関係する事項は極力工場共通規程に織り込み,

表 4 ISO 9002 チェックシート

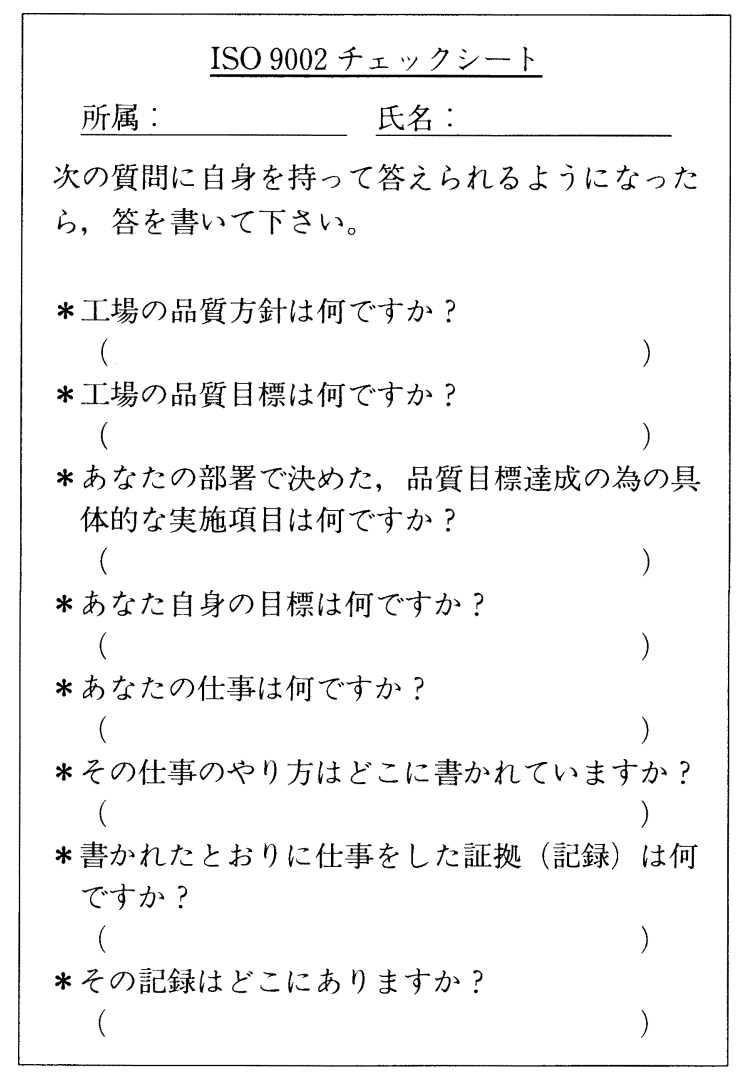

(1) 工場共通規程を必要部署に配布する。

(2) 各部署で作成した文書は作成部署で使用し, 基 本的には他の部署へは配布しない。

(3) 工場共通規程でカバーしきれない場合のみ, 他 の部署に配布する。

様にした。

\section{9 教育・宣伝活動}

認証作業を推進する上で一番重要なことは, 幹部の 理解と意識改革である。

認証作業を推進するためには教育・宣伝が必要であ る。教育は幹部に対してはJQA 講師に講演を依頼し た。係長, 職長に対しては事務局メンバーが, 一般従 業員に対しては, 担当部署のプロジェクトメンバーが, チェックシート（表 4), 想定問答集等で行った。し かし, 実際に教育・宣伝効果が大きかったのは, 内部 品質監査や, 予備審査で, これらを重ねるにつれて 徐々に理解が深まり, 雲囲気が盛り上がってきた。

\section{4. 品質システムの実行}

品質マニュアルを頂点とした文書化が出来たら次に 文書に基づいて実際に作業を行い，作業を点検する。

実際に作業を行うと色々問題点が発生し, 認定スケ ジュールに示すように工場審査直前まで文書（やり 方）の変更・改訂を繰り返した。

文書の変更・改訂を行うたびに担当者へ周知徽底さ せなければならないが, 4 組 3 交代を行っている交代 職場の全員に周知徹底させるには非常に時間が掛かり 大変であった。

\section{5. 内部品質監査}

内部品質監查は, 品質システムが決められた通りに 実行されているかを自らが点検し是正する作業で, ISO でも特徴的な重要項目である。もちろん本審査で も実行状況を番査された。実際に本番査に合格できる かどうかは, 内部品質監査のやり方次第で決まると思 う。

\section{1 内部品質監査員}

内部品質監査員は, 従業員 50 名に対して 1 名の割 合で養成する必要があると言われている。神崎工場で は, 工場で決めた内部品質監査員の資格認定基準に従 って 17 名の監査員を認定している。資格は会社の認 めた内部品質監査員養成セミナーの受講者と受講者 （監査員）から研修を受けた者に与えられる。監査員 は全て認証取得プロジェクトのメンバーで, 社外の講 習で資格を得た者 7 名, 社外講習を受けた者から研修 を受けて資格を与えられた者が 10 名である。 
我々の経験では, 特別な教育や知識より, 試行錯誤 の繰り返しの中で監査の実績を積み重ねて行くことで 監査員のレベルは上がって行ったように思う。

\section{2 内部監査の実際}

神崎工場では, 内部監査員が互いに他部署をチェッ ク寸るという形で本審査までに各部署について 5 回の 内部監査を行った。1 回目, 2 回目の監査では, 監査 員の質問に対してなかなか的確な答が出来なかった。 そこで監査員の方から「この質問に対してはこういう 文書と，記録でこう答えたらどうですか」と言う様に 監査というより被監查部署に対する教育と言う要素が 多かった。実際に内部監査の形になったのは 4 回目以 降からであった。

監査は，予め作成したチェックシートに従って行っ た。チェックシートは色々な参考書に記載されている
のでそれらを参考に作成する事が出来たし，また，監 査の内容によっては参考書に記載された物をそのまま 使うこともできた（表 5)。

監査で行う質問の典型的なパターンは

(1)「あなたの仕事は何ですか？」

(2)「それはどこに書かれていますか？」

(3)「書かれたとおりに仕事をした証拠（記録）は 何ですか?」

(4)「その証拠（記録）はどこにありますか？見せ て下さい」

と, 質問を更に発展させるために

(5)「その仕事をしているとき…起こったらどう しますか?」

(6) (2)(3)(4)と質問を続ける

である。

表 5 内部品質監査千ェックシート

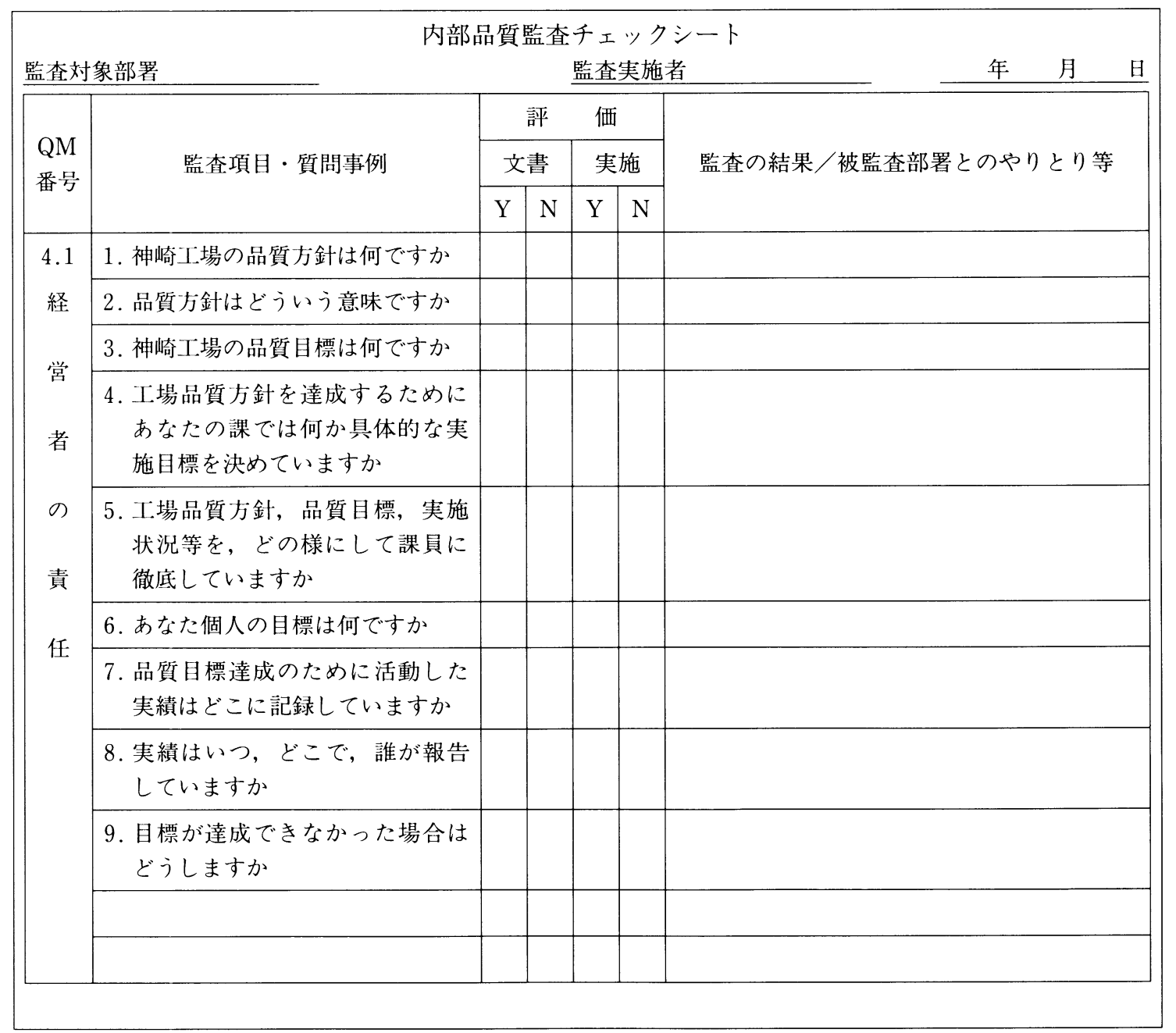



亮

監査というのはサンプルチェックであるので, 監査 で不適合が発見された場合, 被監査部署は指摘された 事項だけでなく, 類似の事例の調査を行って, 必要な ものについて全て是正し報告しなければならない。

本番査でも，指摘された不適合事項に対して類似の 事例の調査が行われ，それらを含めて是正が的確に行
われたことが確認されるまで $\mathrm{OK}$ が出なかった。

\section{6. 予備審 査}

本審査を受ける前に，本審査を受けるに足る品質シ ステムが確立され実行されているかを審査機関が事前 にチェックするのが予備審査である。

表 6 審査プログラム

\begin{tabular}{|c|c|c|c|c|}
\hline 日 & 時 & \multirow{2}{*}{\multicolumn{3}{|c|}{ 項目及び被審査部門 }} \\
\hline 自 & 至 & & & \\
\hline \multicolumn{2}{|c|}{94 年 5 月 24 日 } & チーム 1 & チーム 2 & チーム 3 \\
\hline $9: 00$ & $9: 20$ & \multicolumn{3}{|c|}{ オープニングミーティング } \\
\hline $9: 20$ & $10: 00$ & \multicolumn{3}{|l|}{ 工場見学 } \\
\hline $10: 00$ & $11: 00$ & \multicolumn{3}{|l|}{$\begin{array}{l}\text { 1. 経営者の責任 } \\
\text { 2. 品質システム } \\
\text { (工場長) } \\
\text { (工場長代理) } \\
\text { (生産技術部長) }\end{array}$} \\
\hline $11: 00$ & $12: 00$ & $\begin{array}{l}\text { 3. 契約内容の見直し } \\
\\
\text { (管理部長) } \\
\text { (操業管理課長) }\end{array}$ & $\begin{array}{l}\text { 17. 教育, 訓練 } \\
\\
\text { (総務部長) } \\
\text { (勤労課長) }\end{array}$ & $\begin{array}{l}\text { 1. 経営者の責任 } \\
\text { 2. 品質システム } \\
\\
\text { (工場長) } \\
\text { (工場長代理) } \\
\text { (生産技術部長) }\end{array}$ \\
\hline $12: 00$ & $13: 00$ & \multicolumn{3}{|c|}{ 昼 食 } \\
\hline $13: 00$ & $16: 00$ & $\begin{array}{l}\text { 3. 契約内容の見直し } \\
\text { 7. 製品の識別及びトレ } \\
\text {-サビリティ } \\
\text { 8. 工程管理 } \\
\text { 9. 検査及び試験 } \\
\text { 11. 検査及び試験の状態 } \\
\text { 12. 不適合品の管理 } \\
\\
\text { (管理部長) } \\
\text { (操業管理課長) } \\
\text { (製造部長) } \\
\text { (抄紙課長) }\end{array}$ & $\begin{array}{l}\text { 7. 製品の識別及びトレ } \\
\text { ーサビリティ } \\
\text { 8. 工程管理 } \\
\text { 9. 検査及び試験 } \\
\text { 11. 検査及び試験の状態 } \\
\text { 12. 不適合品の管理 } \\
\\
\\
\text { (製造課長) } \\
\text { (生産技術課長) }\end{array}$ & $\begin{array}{l}\text { 5. 購買 } \\
\text { 6. 購入者による支給品 } \\
\\
\text { (管理部長) } \\
\text { (操業管理課長) } \\
\text { (資材課長) } \\
\\
\text { (株)KS ウイング } \\
\text { (俚:上二部長) }\end{array}$ \\
\hline $16: 00$ & $17: 00$ & \multicolumn{3}{|l|}{ チームミーティング } \\
\hline $17: 00$ & & \multicolumn{3}{|l|}{ レビューミーティング } \\
\hline
\end{tabular}

備考：本プログラムに明記されている部門責任者には, 該当する項目の責任, 権限, 手順等につ いて代表してインタビューします。また，その項目に関連する他の部署に対しても，実際 の活動状況を審査します。 
予備番査は，JQAより番查員が来場して行われた。 ISOの番査が悠際にどのように行われるか全く分って いなかったが，子備審査を受けて，基本的には現場， 現物でのサンプリングによるチェックが基本である事 が分った。また, 子備審査で我々の規格の解釈でよい のか, 規格要求項目に対して我々が行っている方法, レベルでよいのか等がよく理解できるようになった。

当初 11 月に 1 日だけ受ける予定であったが，1日 だけで充分な監査が受けられなかったので更に2月に 2 日間の予備番查を依頼した。

ちなみに, 11 月の子備番查では 31 項目, 2 月の予 備審査では 35 項目の不適合が指摘された。

これらの指摘事項を改善して本審査に臨んな゙。

\section{7. 工場審査}

工場審査は, JQAより 3 人の番査員が来場し, 5 月 24 日から 27 日までの 4 日間を 3 チームに分かれて 行われた。

予め送られてきた番査プログラム（表 6）に従って， チーム 3 は, 経営考の責任, 内部品質監査, 是正処置, 文書管理, 品質記録を中心に監査を行い全社的に品質 システムが確让されているかをチェックした。
チーム 1，2 は，品質システムの実行状態を全部署 を巡回してチェックした。1 項目の所用時間は 1.5 時 間から 2 時間であったが, その間に現場の作業員へも 質問された（表 7)。

1 日の監査終了後レビューミーティングが行われ， 審査状況やその日に見つかった不適合について報告が 行われた。4 日間の審査でマイナーな不適合が 6 件指 摘された。たとえマイナーな不適合でも改善が認めら れるまで認証されない。そこで，審査期間中であれば 審査員と意見交換ができ, 改善が的確に，また早くで きるので, 不適合を指摘された部署は徹夜してその日 の中に是正処置を行った。6 件のうち 5 件は審査終了 までに是正した。

最終日には工場長も出席してクロージングミーティ ングが行われた。この席で主任審査員より不適合とは ならない 7 項目の改善要望（アドバイス）が出された が，神崎工場はISO 9002 規定要求項目に従って品質 システムを運用していることが確認できたので, 残り 1 件について是正処置報告書が提出され是正処置が承 認されたらJQAの認定審査委員会に認定を推薦する と報告されて審査を終了した。

残った是正処置も 3 日後に終了して本審査に無事合

表 7 審査官の質問手順

\begin{tabular}{|c|c|c|c|}
\hline & 質 & & 回 \\
\hline 1 & QC 【程表を見せて下さい。 & 1 & QC 工程表を見せる。 \\
\hline 2 & $\begin{array}{l}\text { この表で生産技術課が行っている検査はどれです } \\
\text { か？ }\end{array}$ & 2 & 測定担当欄が生産技術課となっているものです。 \\
\hline 3 & この涂料の規格はありますか？ & 3 & 規格表を提示する。 \\
\hline 4 & $\begin{array}{l}\text { この塗料で生産技術課が行う検査を説明して下さ } \\
\text { い。 }\end{array}$ & 4 & ブツ，ハジキ，導電性について説明する。 \\
\hline 5 & $\begin{array}{l}\text { 導電性はどの様な測定器で測定しますか？ } \\
\text { 校正はどのように行っていますか? }\end{array}$ & & $\begin{array}{l}\text { 測定器を見せる。 } \\
\text { 年 } 1 \text { 回, 計装課が校正している。 }\end{array}$ \\
\hline 6 & $\begin{array}{l}\text { 雓料の試験表を見せて下さい。 } \\
\text { (試験表を見て) 濃度と粘度の測定值が規格值と } \\
\text { ずれていますね。 }\end{array}$ & 6 & $\begin{array}{l}\text { 古い書式を間違って使っています。 } \\
\text { 規格変更を行って新しい書式を使用しています。 } \\
\text { (新書式の記録を示して) このように規格に入っ }\end{array}$ \\
\hline & つけてトさい，矢点になります。 & & ています。 \\
\hline 7 & ブッというのはどんなものですか？ & 7 & 外観見本を取り出して説明する。 \\
\hline 8 & 記録濃度の記録を見せて下゙さい。 & 8 & 判定書を提示する。 \\
\hline 9 & 測定值が卜限いっぱいですね & 9 & w...... \\
\hline 10 & $\begin{array}{l}\text { 諧調の䘚現が規格書ではStep, 判定書ではms } \\
\text { となっていますが？ } \\
\text { 间一の衣現にして置いてトさい。 }\end{array}$ & 10 & 同じ事ですが正しいのは ms です。 \\
\hline
\end{tabular}


格することが出来た。

\section{8. おわりに}

認証取得という目標に向かってひなすら進み，なん とか審査に合格できるようにつじつま合わせに作った 部分も多い。認証を取得した今，この品質システムを 改善し軌道に乗せていくことが大切である。

認証取得活動を進めてきた中での一番の成果は, 全 員の品質に対する意識が高まったことである。更に, 工場審査前の 1 力月間, 自分の部署の責任で不合格に ならないようにと一丸となって頑張り全員で認証取得 の喜びをわかちあえたことも大きな成果であった。

ISO の場合, 認証取得後も年 2 回のフォローアップ 監査があり，取った後は中だるみというわけにはいか
ない。神崎工場にとって最適なシステムに改善してゆ くことで, 操業, 品質の安定に寄与するものと考える。 参考文献

- 品質保証の国際規格：監修 久米均 (日本規格協会)

・ISO 9000 運用実務マニュアル：PL 研究所編（日 本能率協会)

・ISO 9000 総合ハンドブック：須藤㴊一 他（化学工 業日報社)

- 社内標準事例集：(社)日本技術士会 ISO 研究会編 (新技術開発センター)

・ISO 9000 実務ハンドブック：日本 IBM/(侏アイメ 又編（新技術開発センター）

·工場管理：Vol. 40 No. 1 (1994) 